\title{
Wanda Świątkowska
}

Uniwersytet Jagielloński w Krakowie

\section{KONCEPCJE TEATRU SPOŁECZNIE ZAANGAŻOWANEGO WEDLUG JULIUSZA OSTERWY}

Choć Juliusz Osterwa był uwielbianym aktorem, reżyserem, pedagogiem, organizatorem i teoretykiem teatru oraz gwiazdą polskich scen, jego córka Maria Osterwa-Czekaj mówi o nim przede wszystkim jako o społeczniku. ${ }^{1}$ Mamy tu do czynienia ze swoistym paradoksem, który dostrzegł już Józef Szczublewski, wielokrotnie podkreślający w Żywocie Osterwy, że artysta, mogąc być świetnie opłacaną gwiazdą scen stołecznych czy w końcu dyrektorem nowo powstałego Teatru Narodowego, zamiast gładko i efektownie planować swą karierę, wybierał często rozwiązania zaskakujące opinię publiczną, ryzykowne i niegwarantujące sukcesu kierunki działań, które motywowane były nie jego osobistym interesem, lecz misją społeczną, służebnym rozumieniem sztuki teatru i walką o ideę. Biograf ironicznie nazywał Osterwę nieprzytomnym fantastą, a jego zapędy - mrzonkami, pogonią za chimerami, marzeniami i maniackimi imprezami. ${ }^{2}$ Sam Osterwa, doskonale świadomy swej sytuacji, jak i krążących o nim złośliwych plotek, pisał w liście do Lucyny Kotarbińskiej:

Muszę pochwalić człowieka (choćbym nim sam był), który mogąc grać „,z założoną nogą na nogę" - i zgarniać co miesiąc pokaźną sumkę - woli nie ostrzyżony i bez lakierków karczować, orać, sadzić - na przyszłość. ${ }^{3}$

O tym podwójnym wizerunku Osterwy mówił po latach również Jerzy Grotowski, który na spotkaniu zorganizowanym w dwudziestą piątą rocznicę śmierci artysty, stwierdził:

bardzo osobliwego zabiegu dokonywano na żywocie Osterwy. Zabiegu, który zawsze polegał na próbie, aby go zredukować do kogoś sympatycznego, miłego, beztroskiego, uroczego, pełnego

1 Córka społecznika, z Marią Osterwą-Czekaj rozmawia Wanda Świątkowska, „Performer” 2011 $\mathrm{nr}$ 3, http://www.grotowski.net/performer/performer-3/corka-spolecznika.

2 Zob. J. Szczublewski, Żywot Osterwy, Warszawa 1973, s. 277-278, 294.

3 Listy Juliusza Osterwy, listy zebrała E. Osterwianka, red. E. Krasiński, Warszawa 1968, s. 76. 
wdzięku, cudownie grającego role komediowe, kogoś, kto tak przyjemnie z ludźmi rozmawia, a kiedy z artystą dramatycznym pracuje jako reżyser, tak potrafi mu skorygować to, co on robi, że ten się nie obrazi, przeciwnie, że właśnie cały rozkwitnie i pewny pójdzie naprzód i rola mu wyjdzie... ${ }^{4}$

$Z$ tego obrazu usuwano natomiast według Grotowskiego to, co „było podstawą istnienia Osterwy - ziarnem jego życia”, odwracano uwagę „od istotnego powołania, od istotnej tęsknoty, którą ten człowiek symbolizował”. „To, co najistotniejsze w jego działalności - twierdził Grotowski - było najbardziej ośmieszane". Lekceważono powołanie i misję, których realizacji poświęcił Osterwa całe swoje życie. Tymczasem, według Grotowskiego, to właśnie był heroizm i coś, co zasługiwało na największy szacunek ze strony tak jego współpracowników, jak i kolejnych pokoleń. „Prowadziła go jakaś inna tęsknota” - pisał Grotowski - pogoń za „potrzebą sensu”, marzenie o wyjściu z błota teatru

ku innej perspektywie, gdzie człowiek mógłby się z człowiekiem spotykać wokół czegoś, co ma jakiś sens, jakiś cel, jakąś czystość, czego można by się nie wstydzić. ${ }^{5}$

Grotowski przyznał, że odczuwa ludzką bliskość i wielki szacunek wobec Osterwy. Wyznał, że rozumie, „o co Osterwie chodziło” i nazwał siebie kontynuatorem jego idei. Twórca Teatru Laboratorium wyraźnie dostrzegł u Osterwy bliską mu, choć inaczej realizowaną, chęć wyjścia poza teatr, uczynienia ze sztuki narzędzia, które miałoby moc zmienić człowieka i rzeczywistość.

Dla przybliżenia koncepcji sztuki społecznej według Juliusza Osterwy i działalności Reduty pod kątem jej społecznego zaangażowania, najważniejsze są trzy punkty jego artystycznej drogi: realizacja dramatu Stefana Żeromskiego Uciekła mi przepióreczka... i sprzęgnięcie własnej osoby i koncepcji z ideą przedstawioną w dziele, działalność Reduty objazdowej oraz wojenne koncepcje Teatru Społecznego. Pozwalają one pokazać, jak Osterwa rozumiał kwestie zaangażowania społecznego, z czego te idee wyrastały i jak zmieniały się przez lata jego aktywności.

\section{PRZEŁĘCKI NARODOWEJ SCENY, CZYLI IDEOWY WPLYW PRZEPIÓRECZKI}

Prapremiera dramatu Żeromskiego Uciekła mi przepióreczka... w reżyserii i z główną rolą w wykonaniu Osterwy odbyła się 27 lutego 1925 w Teatrze Narodowym. Żeromski był pisarzem od początku związanym z Redutą - na jej inaugurację 29 listopada 1919 Osterwa wystawił Ponad śnieg bielszym się stanę..., potem w kręgu Reduty powstały dramaty: Biała rękawiczka (1920) i Turoń (1921, praprem. 24 IV 1923). Popisową rolą Osterwy już od 1917 była tytułowa postać z dramatu Żeromskiego Sułkowski (1910).

4 J. Grotowski, [Wypowiedź na spotkaniu Osterwa po ćwierćwieczu,] [w:] idem, Teksty zebrane, zespół red. A. Adamiecka-Sitek et al., Warszawa 2012, s. 547.

Ibidem, s. 549. 


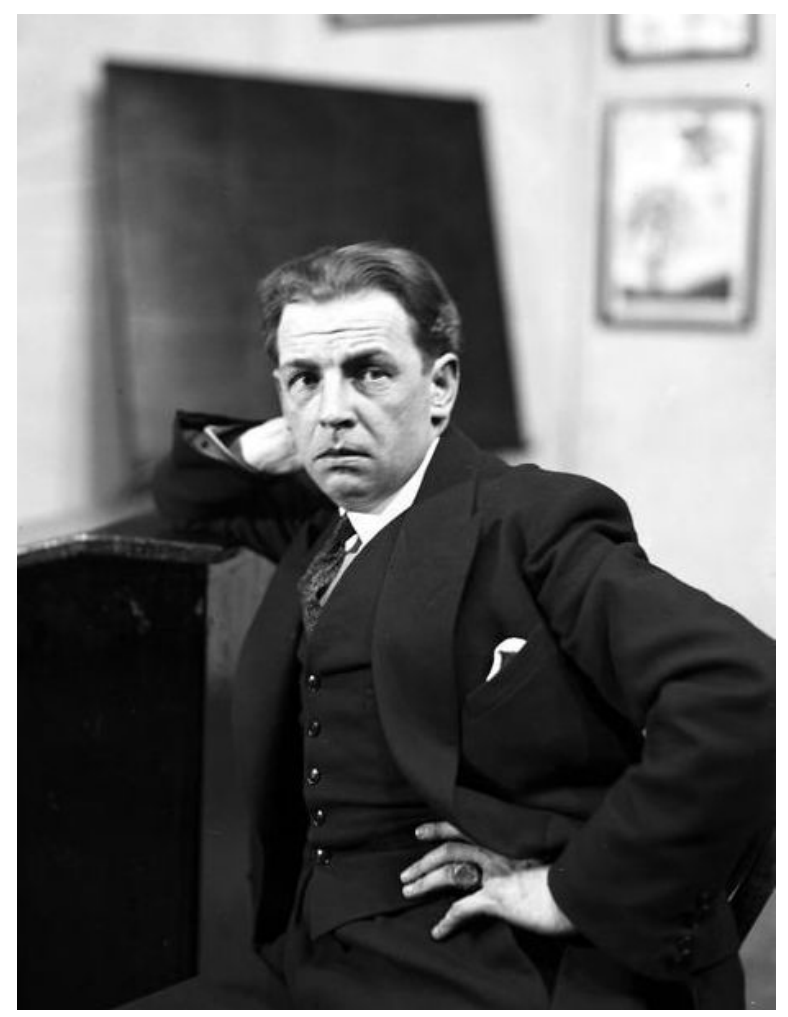

Juliusz Osterwa jako Przełęcki w sztuce Stefana Żeromskiego Uciekła mi przepióreczka..., występy gościnne w Krakowie, 1929

Do dziś pokutuje przekonanie, że Żeromski był lepszym powieściopisarzem niż dramatopisarzem, jego dramaty były uznawane za „niesceniczne” i nie miały wielkiego powodzenia $\mathrm{w}$ teatrach. To miał zmienić dopiero Osterwa i sukcesy inscenizacji w Reducie. Właściwie to Osterwa gorąco namawiał Żeromskiego do pisania dramatów i przekonywał go do współpracy z teatrem. Żeromski odwdzięczył się dramatami dedykowanymi aktorowi i pisanymi z myślą o nim jako o odtwórcy głównych i najważniejszych postaci.

Jest to też przypadek Przepióreczki. Dramat powstawał pomiędzy połową 1923 a styczniem 1924. Jeszcze w styczniu Żeromski przekazał sztukę Osterwie i, jak głosi legenda, „Osterwa przeczytał i upił się ze szczęścia”. ${ }^{6}$ Po pierwsze była to sztuka z doskonale naszkicowanymi postaciami, szczególnie głównym bohaterem, profesorem fizyki - Przełęckim, który miał szansę stać się wirtuozowskim popisem w rękach takiego aktora jak Osterwa, i ze świetną rolą wiejskiego

6 J. Szczublewski, op. cit., s. 255. 


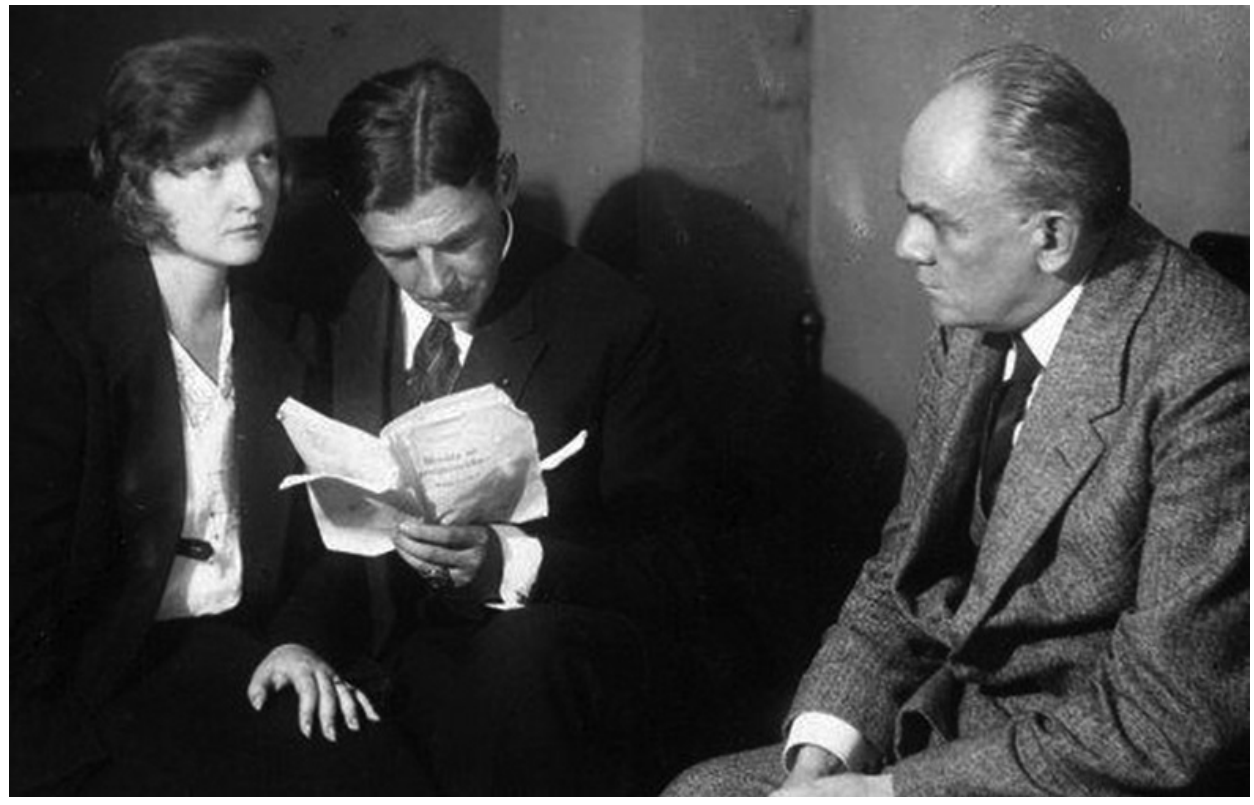

Maria Malanowicz-Niedzielska i Juliusz Osterwa ze Stefanem Żeromskim

nauczyciela - Smugonia, stworzoną wprost dla Stefana Jaracza. Po drugie, w idealizmie Przełęckiego Osterwa odnajdywał także swoje własne marzenia, a wybrana przez bohatera droga potwierdzająca konieczność poświęcenia osobistego szczęścia dla idei była czymś, co Osterwa znał z własnego doświadczenia. Ten romantyczny z ducha konflikt Żeromski doskonale uchwycił i ujął w formę dramatyczną. Po trzecie, sztuka ta odpowiadała Osterwie ideowo - przedstawiona przez Żeromskiego idea regionalizmu, szerzenia oświaty i pracy wśród ludu była bliska społecznikowskim zapędom Osterwy. Wzruszony Osterwa dziękował w liście Żeromskiemu:

Czytając po raz drugi i wczytując się - doznawałem uczucia niepokojąco wzruszającego. Ach, Panie Stefanie. Czym ja okażę, jak wyrażę swoją miłość dla Pana i wdzięczność za to, co Pan napisał. Zostanie w naszym żelaznym repertuarze. Perła nasza najdroższa. Nie powiem nic, nie będę zapowiadał nic. Proszę mi zostawić swobodę obsady. [...] Pragnę obsadzić tak i pokazać tak, żeby nie patrzono jak na „sztukę teatralną” - ale żeby widziano i wdychano w siebie, i raz na zawsze zapamiętano - i ciągle sobie przypominano. ${ }^{7}$

Żeromski nawiązał w dramacie do popularnej w II Rzeczypospolitej idei regionalizmu. Jej twórcą był Aleksander Patkowski, którego rysy można odnaleźć

7 Listy Juliusza Osterwy, op. cit., s. 60-61. 
w osobie Przełęckiego. ${ }^{8}$ Patkowski był nauczycielem, społecznikiem, krajoznawcą, miłośnikiem ziemi sandomierskiej i działaczem na rzecz środowiska lokalnego. W 1922 zorganizował w Sandomierzu regionalne kursy oświatowe, efektem których było założenie Powszechnego Uniwersytetu Regionalnego im. Stanisława Konarskiego. Propagował on ideę regionalizmu, którą można rozumieć jako umiłowanie małych ojczyzn, połączone z pozytywistyczną pracą u podstaw na rzecz lokalnej kultury, poznawania historii i tradycji regionu.

Hasłem regionalizmu jest: „od poznania swojego regionu do poznania swojego kraju". Był to ruch umysłowy mający na celu rozwój kulturalny, gospodarczy i społeczny prowincji. Zmierzał do rozwoju samorządności i pracy na rzecz własnego regionu. Regionalizm przejawiał się w organizowaniu kursów krajoznawczych, muzeów etnograficznych i przyrodniczych, tworzeniu lokalnych ośrodków kultury, wprowadzaniu do szkół przedmiotów dotyczących edukacji regionalnej. ${ }^{9}$ Żeromski korespondował z Patkowskim w okresie pisania Przepióreczki, był zaangażowany w działania na rzecz swej rodzinnej kielecczyzny. Organizował kursy dokształcające dla uczniów szkoły rzemieślniczej, był inicjatorem Uniwersytetu Ludowego, opiekunem ochronki dla dzieci i współtwórcą amatorskiej trupy teatralnej. Pisał książki publicystyczne na temat reformy życia zbiorowego, organizacji pracy, oświaty i kultury w powojennej Polsce, np. Początek świata pracy (1918), Organizacja inteligencji zawodowej (1919), Snobizm i postęp (1922). Idee propagowane przez Patkowskiego i Żeromskiego miał wkrótce zrealizować sam Osterwa, a ich patronem stał się docent Przełęcki.

Premiera Przepióreczki w Teatrze Narodowym okazała się wielkim sukcesem - „świętem teatru i świętem literatury”. ${ }^{10}$ Spektakl zagrano w doborowej obsadzie, oprócz Osterwy i Jaracza wystąpiły w nim inne gwiazdy ówczesnego teatru, m.in. Ludwik Solski, Józef Kotarbiński, Józef Śliwicki, Władysław Staszkowski, Józef Chmieliński, Tekla Trapszo. Przedstawienie powtórzono 60 razy z rzędu. W recenzjach nie szczędzono pochwał odtwórcy głównej roli. Tadeusz Boy-Żeleński pisał:

Jest to rola niesłychanie trudna: pogodzić jej nadludzki zaiste heroizm z lekkim komediowym tonem, w jakim jest utrzymana, to jedno z najbardziej karkołomnych zadań aktorskich, jakie znam. Pan Osterwa jest może jedynym w Polsce aktorem, który mógł się jej podjąć. ${ }^{11}$

Franciszek Siedlecki dodawał, że Osterwa w Przełęckim

uchwycił istotę tej postaci polegającą na zapatrzeniach mistycznych, tłumaczących jej na pozór nieludzkie czy nadludzkie czyny [...] dał na scenie typ człowieka nowoczesnego, unikającego patosu,

8 Zob. Uwagi wydawcy, [w:] S. Żeromski, Pisma zebrane, red. Z. Goliński, seria 3, Dramaty, Warszawa 2004, s. 307-320.

9 Zob. Z. Puławski, Aleksander Patkowski - twórca regionalizmu polskiego (2010), http://www. forum.sandomierskie.pl/patkowski.html.

10 J. Szczublewski, Pierwsza Reduta Osterwy, Warszawa 1965, s. 260.

11 Cyt. za: J. Szczublewski, Żywot Osterwy, op. cit., s. 273. 
chowającego swe najgłębsze uczucia i zamyślenia pod maską lekkoducha, a okazującego swą duchową moc jak błyskawice w chwilach, kiedy go do tego duszna atmosfera wypadków zmusza. ${ }^{12}$

Rola Przełęckiego to według recenzentów szczyt umiejętności aktorskich Osterwy. Zagrał ją bez fałszu, hipnotyzując i uwodząc widownię niemal tak, jak jego bohater.

Dramat zdaniem recenzentów był nie tylko napisany dla Osterwy, ale wręcz inspirowany jego osobą i działalnością. Michał Orlicz pisał:

Krystaliczny charakter i dynamika życiowa Osterwy, społeczny aspekt jego pracy artystyczno-wychowawczej, rozmach organizacyjny, zdolność improwizacji, radość starcia się z przeciwnikiem i upajanie się swą rolą wobec słuchaczy, wdzięk i kunszt retorycznego dowodzenia swej racji, zapamiętałość w rzeczach idei i etyki, gesty wodzowskie na uśmiechu czarującym i uwodzicielskim - splotły się w obserwacjach Żeromskiego w gotową postać Przełęckiego. ${ }^{13}$

Wtórował mu Boy-Żeleński:

Żeromski zbliżył się z Redutą w pełni jej rozkwitu z okazji wystawienia Ponad śnieg; widział Osterwę w rolach różnych „fircyków” i „lekkoduchów” stanowiących jego specjalność, widział go zarazem jako organizatora, proroka i hipnotyzera małego społeczeństwa, jakim była ówczesna Reduta. I napisał swoją wersję „fircyka” - jakim parokrotnie mienią Przełęckiego koledzy; zapragnął w swoim lekkoduchu skojarzyć wdzięk i humor z powagą i głębią wiary, z żarem umiłowania i bohaterskiej ascezy. I kto wie, czy pewne niemożliwości figury Przełęckiego nie tłumaczą się tym, że modelem jego był nie jakiś rzeczywisty człowiek - lub idea rzeczywistego człowieka - ale aktorstwo i talent aktora. ${ }^{14}$

Rola docenta, poświęcającego dla idei miłość i swoje dobre imię, była nie tylko wielkim sukcesem Osterwy, ale przede wszystkim ważnym dla niego osobistym doświadczeniem. Szczublewski pisał:

Wraz z tą sztuką Osterwa osiąga wierzchołek swej kariery aktorskiej, reżyserskiej i dyrektorskiej. ${ }^{15}$

Paradoksem jest, że właśnie wtedy rozebrano sale redutowe i Reduta została dosłownie eksmitowana na bruk. Osterwa został dyrektorem Teatru Narodowego i cieszył się niesłabnącym powodzeniem jako gwiazda stołecznej sceny, a sukces Przełęckiego utwierdził jego status. I co robi w tej sytuacji Osterwa? Składa dymisję.

Pomiędzy pięćdziesiątym a sześćdziesiątym przedstawieniem Przepióreczki Osterwa porzuca Warszawę i Teatr Narodowy (w maju 1925) i przenosi się z Redutą

\footnotetext{
$12 \quad$ Ibidem, s. 276.

13 M. Orlicz, „,Uciekta mi przepióreczka...”. Kompozycja autorska i realizacja sceniczna, cyt. za: M. Białota, Dramaty Żeromskiego w Reducie. Z zagadnień inscenizacji i recepcji krytycznej, Wrocław 1989, s. 81.

14 T. Boy-Żeleński, Perfumy i krew. Wrażenia teatralne, cyt. za: ibidem, s. 82.

15 J. Szczublewski, Pierwsza Reduta Osterwy, op. cit., s. 261.
} 


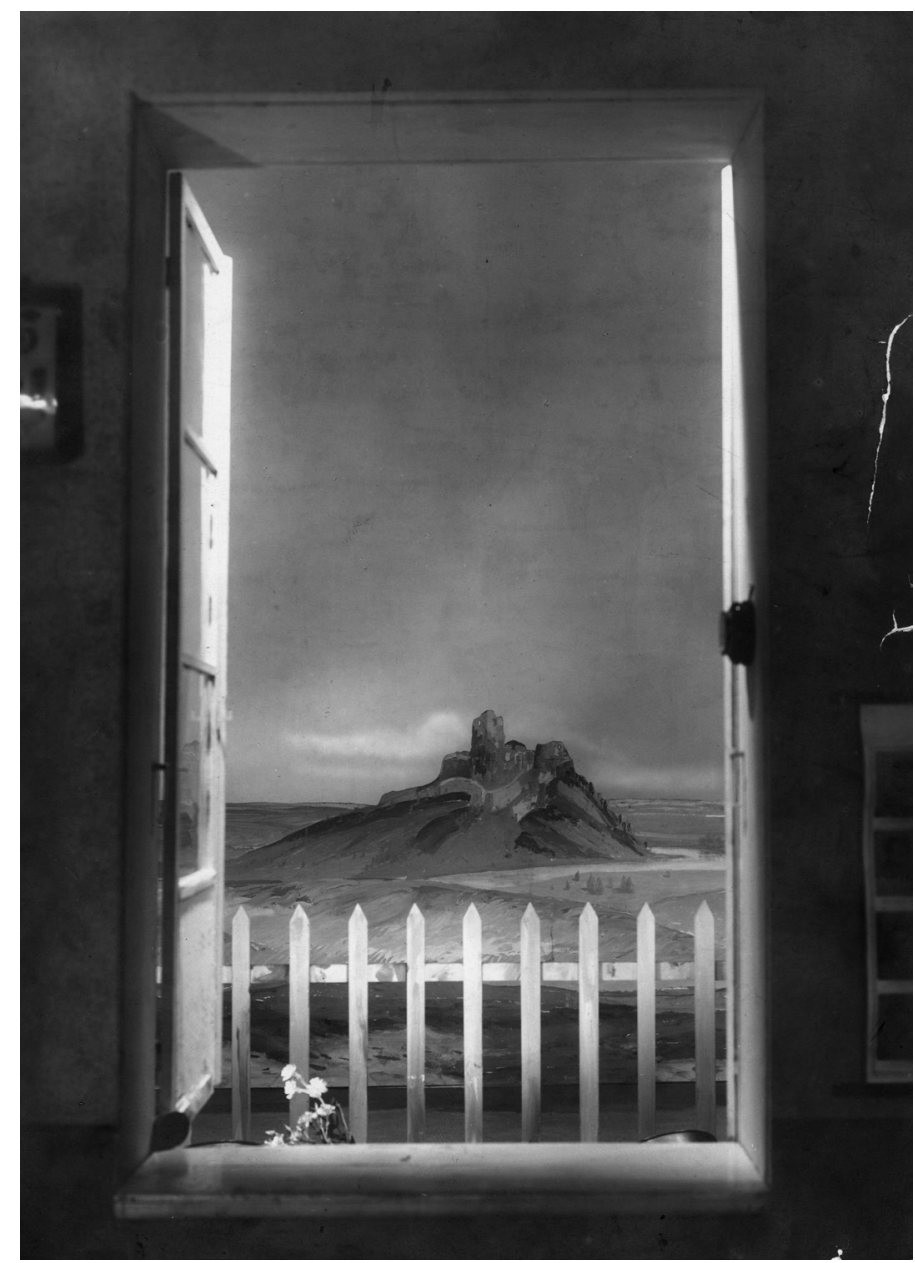

Zdjęcie dekoracji Aleksandra Kozłowskiego do sztuki Stefana Żeromskiego Uciekła mi przepióreczka..., Teatr Narodowy 1925

do Wilna - „szlachetnie, niemal tak jak Przełęcki w finale Przepióreczki” ${ }^{16}$ Rezygnuje z sukcesu, własnego powodzenia - dla idei. Ten gest dopełnił utożsamienia Osterwy z Przełęckim. Odtąd widzowie mówili o nim „Juliusz Przełęcki” (w sztuce miał na imię Edward) lub „Przełęcki narodowej sceny”. ${ }^{17}$

Osterwa odszedł, by stworzyć w Wilnie redutową placówkę teatralną i organizować życie teatralne na prowincji. W okresie wileńskim był propagatorem idei regionalizmu, społecznikiem i romantycznym pozytywistą -

\footnotetext{
16 Ibidem, s. 262.

17 Zob. J. Szczublewski, Żywot Osterwy, op. cit., s. 297.
} 
i tak jak Przełęcki był natchnieniem dla porębiańskich profesorów, tak Osterwa był w dużym stopniu inspiratorem ożywienia działalności kulturalno-społecznej młodzieży akademickiej w Wilnie. ${ }^{18}$

Idea pracy u podstaw, wpisana $\mathrm{w}$ dramat Żeromskiego, została zrealizowana przez Redutę wędrowną. 1 września 1925 Osterwa wyruszył z Przepióreczka w objazd, który trwał z przerwami do 6 grudnia 1925. W liście do Żeromskiego pisał:

Oto, jak przed sześciu laty zaczynaliśmy Redutę warszawską Pańskim utworem, tak i teraz rozpoczynamy swoją działalność ,regionalną” od Przepiórki. ${ }^{19}$

Według zestawienia repertuaru opracowanego przez Ludwika Simona, w okresie Reduty wileńskiej odbyły się 193 pokazy dramatu Żeromskiego (148 w objeździe i 45 przedstawień w siedzibie) ${ }^{20}$. Ostatni przedwojenny objazd z Przepióreczka trwał od 1 maja do 6 lipca 1938. Po raz ostatni Osterwa wystąpił w roli Przełęckiego dwa lata przed śmiercią, w 1945 w Krakowie. Przepióreczka i postać docenta fizyki zrosły się z nim na zawsze.

Osterwa traktował dramat Żeromskiego jako coś więcej niż „,sztukę teatralną" - jak pisał w cytowanym już liście. Idea przedstawiona w dziele - etos pracy, ofiarnicze poświęcenie, odpowiedzialność, wierność raz obranym ideałom, bez względu na cenę - była najpełniejszym wyrazem jego własnych przekonań. Przepióreczka zmobilizowała artystę do działania - porzucenia kariery w stolicy i wyjazdu na prowincję - oraz traktowana była jako programowy tekst Reduty, w której wierność idei, troska o dobro wspólne powinny dominować nad jednostkowym interesem.

Dlatego tak boleśnie odebrał Osterwa atak Jana Kotta po premierze Przepióreczki w 1945 w Krakowie, gdy krytyk zarzucił mu, że dramat Żeromskiego jest dziełem anachronicznym i sentymentalnym, a postawa Przełęckiego to w istocie wyraz egoizmu i samouwielbienia. ${ }^{21}$ Przełęcki, jak dowodził Kott, przynależy do pokolenia szlacheckich indywidualistów, ,arystokratów ducha" i nie może być wzorem dla nowoczesnego społeczeństwa. W istocie był to atak na formację artystów wychowanych na ideach Młodej Polski i na tak ważny dla nich polski etos romantyczny z towarzyszącym mu postulatem poświęcenia i konieczności ofiary (pod którym krył się zawoalowany atak na Powstanie Warszawskie). ${ }^{22} \mathrm{~W}$ niepublikowanej wówczas polemice z Kottem Osterwa pisał:

Przełęcki, skoro mu ofiarowano dar, z którym może robić, co będzie uważał za stosowne - zrzekł się tego daru na rzecz Stowarzyszenia, które sam spowodował. Zrzeka się przy tym i zwierzchnictwa nad Stowarzyszeniem, bo wie, że jego sprawa - czynienia komuś dobrze - na tym tylko zyska.

18 Ibidem, s. 337.

19 Listy Juliusza Osterwy, op. cit., s. 66.

20 Spis przedstawień Zespolu Reduty w ciagu dziesięciu lat 1919-1929. Repertuar, oprac. L. Simon, nakładem Zespołu Reduty, Wilno 1929, s. 221-223.

21 J. Kott, Uciekła nam przepióreczka..., „Odrodzenie” 1945 nr 16.

22 Zob. D. Kosiński, A ja za nia, nieboraczek boso..., „Dialog” 2004 nr 9. 


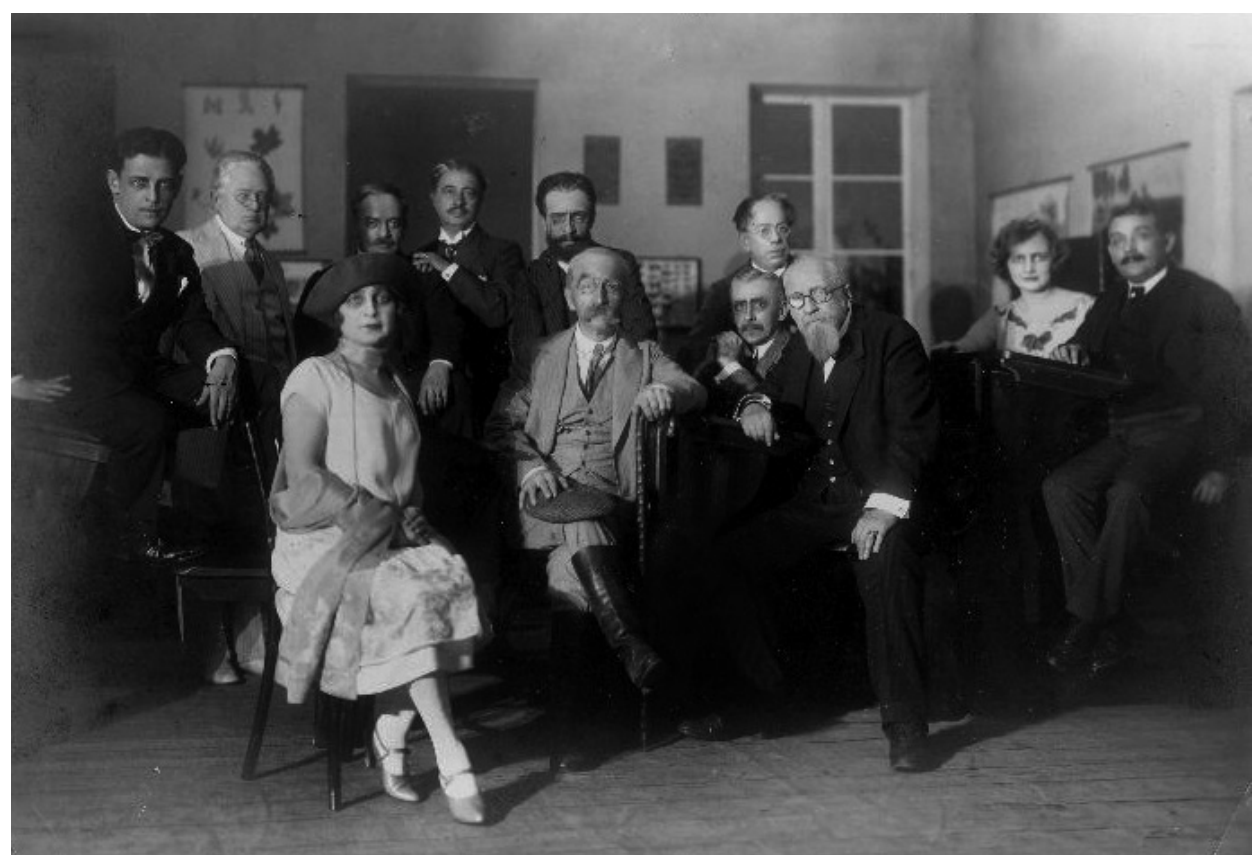

Uciekła mi przepióreczka... Stefana Żeromskiego, Teatr Narodowy 1925

Miłość męża i niewiasty jest skarbem jest siłą, źródłem podsycającym i zasilającym życie twórcze. Przełęcki zrzeka się i tej miłości. I to jest pokazane w Przepióreczce jako przykład, jako wzór wyrzeczeń się niezbędnych dla urzeczywistnienia najgłębszych zamierzeń woli. Dla dobra ogólnego.

Zależało Żeromskiemu, aby unaocznić społeczeństwu typ współczesnego mu działacza i tego działacza obyczaje. ${ }^{23}$

Przełęcki był dla Osterwy „,wzorem wyrzeczeń” - poniósł największą osobistą ofiarę dla urzeczywistnienia idei, która była ,ziarnem jego życia”. Jego poświęcenie, niemal zniszczenie siebie potwierdziło siłę tej idei. Przepióreczka ukazywała pewien etos - wagę służby dla idei, która powinna dominować nad dobrem partykularnym i egoistycznymi celami.

Najważniejszym zaś aspektem dramatu było według Osterwy jego żywe oddziaływanie i moc zmieniania ludzkich decyzji i wyborów. Aktor wspomina dwa takie przypadki: w Wilnie pomiędzy 1925 a 1929 rokiem pokaz Przepióreczki odwiódł zdesperowanego oficera od zamiaru popełnienia samobójstwa. W 1938 w Janowej Dolinie przedsiębiorca, który obejrzał Przepióreczkę, nie ustąpił wobec przeciwności i otworzył kopalnię bazaltu, która dała zatrudnienie czterem tysiącom ludzi. Człowiek ten wszedł na scenę i powiedział:

23 J. Osterwa, Przełęcki - Porębiany, po 14 V 1945, [w:] idem, Z zapisków, wybór i oprac. I. Guszpit, Wrocław 1992, s. 193-194. 
jakaś olbrzymia siła, upór i zawziętość pracy wstąpiła we mnie. Wróciłem tu i zacząłem kopać. [...] Zawdzięcza się to Przepiórce. ${ }^{24}$

Te dwa przykłady świadczą według Osterwy o ideowej sile dramatu, o tym, że ma on realny wpływ na postawy ludzi i może zmieniać rzeczywistość. „Dość, że Przepiórka działa, więc żyje - pisał - i że oddziaływa na żyjących". ${ }^{25}$ Dramat Żeromskiego promuje postawę rezygnacji dla idei z dobra osobistego - swym wyjazdem z Warszawy Osterwa pokazał, jak zrealizować ją w praktyce. Można zaryzykować stwierdzenie, że to Żeromski pchnął go w Polskę, uświadamiając mu swym tekstem konieczność działań, a nie tylko głoszenia ze stołecznej sceny pięknych słów o poświęceniu. ,Jak pojmuje się pracę dla ojczyzny - uczy przykład Przełęckiego"26 - podkreślał Osterwa. Według niego Żeromski pisał po to, by zachęcać ludzi do pracy, a Redutowe pokazy Przepióreczki były dowodem żywego działania tego utworu. Wartość dzieła sztuki mierzy się jego praktyczną skutecznością i społecznym oddziaływaniem. ${ }^{27}$

\section{MISJA SPOŁECZNA OBJAZDÓW REDUTY (1924-1939)}

Objazdy Reduty po kraju odbywały się regularnie i systematycznie od 1924 aż do wybuchu drugiej wojny światowej. Wyprawom, podczas których w miastach, małych miasteczkach i wsiach prezentowano dzieła polskiej głównie dramaturgii, już w założeniach przyświecały cele ideowe: krzewienie polskiej kultury, ożywienie życia intelektualnego na prowincji, edukacja i zapewnienia widowisk o doskonałym poziomie artystycznym społecznościom, które pozbawione były miejscowych teatrów. O „celach i zadaniach” pisał wyraźnie Michał Orlicz, formułując zamierzenia Reduty wędrownej:

Plan ten polegał nie tyle na opanowaniu jak największej liczby miejscowości, ale przede wszystkim na takiej koncentracji widowisk, aby tam, gdzie zachodziła tego potrzeba, ze względu na głód artystyczny i pewien bezruch społeczno-narodowy, spowodować widowiskami o silnym podkładzie ideowym, podniesienie się tętna i natchnąć optymizmem i wiarą te warstwy prowincjonalne, które odcięte od intelektualnych środowisk kraju, zdane były na zaskorupienie w szarzyźnie dnia i monotonii ścierań się czysto lokalnych.

Wyjazd Reduty miał przeto na celu nie tylko dawanie przedstawień i wywoływanie wzruszeń ideowych i estetycznych - ale także rozwinięcie inicjatywy w rozbudowaniu i ożywieniu życia społecznego na prowincji. ${ }^{28}$

Rzeczywiście to, czego dokonała Reduta w latach 1924-1939, nie da się porównać z niczym w skali ówczesnego teatru europejskiego. Zespół docierał ze

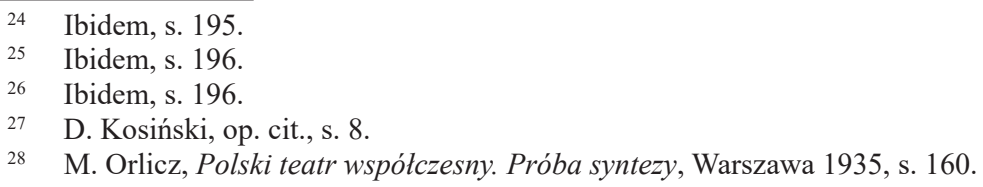


spektaklami do wsi i miasteczek, a co istotne, wracał w te same miejsca ponownie podczas kolejnych wakacji, dzięki czemu tworzył nową, trwałą wartość i wychowywał wiernych sobie widzów. Szczublewski nazwał Redutę objazdową „najlepszym teatrem wędrownym w dziejach polskiej sceny". ${ }^{29}$

Zygmunt Nowakowski z perspektywy czasu tak oceniał zasługi Reduty objazdowej i niezwykły wyczyn jej kierownika:

Lekki, najlżejszy na świecie amant Juliusz Osterwa jest człowiekiem olbrzymich zasług. Powiedziano kiedyś o Kraszewskim, że on nauczył Polaków czytać, bez najmniejszej zaś przesady rzec można o Osterwie, że nauczył Polaków chodzić do teatru. Jego Reduta przeorała swym pługiem całą Polskę, w szczególności zaś Kresy Wschodnie, docierając tam, gdzie albo nigdy nie było teatru, albo gdzieś istniały przed dwoma wiekami prywatne sceny magnackie lub teatry szkolne, konwiktowe, jezuitów, bazylianów, teatynów itd. [...]

Tłukł się po kresach Osterwa, z pozoru rozkapryszony, chimeryczny, zepsuty kochanek Melpomeny, bóstwo Warszawy, ulubieniec wszystkich naszych stolic, który miał niepomiernie silną wolę i postanowił steatralizować Polskę, pokazać teatr zdumionym oczom najgłębszej, zakazanej prowincji. Mógł oddychać codziennym, niezawodnym sukcesem, mógł zgarniać wszystkie kwiaty Warszawy, ale on wolał tę orkę, tę siejbę, to żniwo na bezdrożach Wołynia, rozlewiskach Polesia, na krańcach województw Rzeczypospolitej ${ }^{30}$.

Osterwa postawił sobie za cel stworzenie idealnego teatru objazdowego - doskonałego pod względem artystycznym i perfekcyjnego pod względem organizacyjnym. Było to bardzo nowoczesne przedsięwzięcie, angażujące do współpracy Polskie Koleje Państwowe, władze wojewódzkie, powiatowe, lokalne władze miejscowości, przy zdecydowanym wsparciu Rządu Rzeczypospolitej, Ministerstwa Wyznań Religijnych i Oświecenia Publicznego, Ministerstwa Komunikacji i Ministerstwa Spraw Wojskowych. ${ }^{31}$ Celem Reduty objazdowej było przede wszystkim upowszechnienie teatru, dotarcie z przedstawieniami do każdego zakątka Polski. Można powiedzieć, że skoro Przełęcki wyznaczył Osterwie cel działania, to Reduta wędrowna była wypracowanym w praktyce sposobem jego realizacji.

Pierwszy objazd w roku 1924, pod przewodnictwem Mieczysława Limanowskiego, wynikał w dużej mierze ze względów praktycznych. Reduta pod koniec sezonu 1923/1924 utraciła sale redutowe w Teatrze Wielkim i była na etapie przeprowadzki do Wilna. Ostatni pokaz warszawski odbył się 18 maja 1924, po czym Osterwa wypchnął Redutową gromadkę w Polskę. Ponad siedemdziesiąt osób z Zespołu i Instytutu wyruszyło 20 maja w kierunku Dęblina, gdzie czekały na nich wagony. Pomiędzy 21 maja a 16 lipca odwiedzili 34 miasta, mając w repertuarze pięć przedstawień: W matym domku, Dom otwarty, Pastorałkę, Wielkanoc i Pochwatę wesolości.

29 J. Szczublewski, op. cit., s. 285.

30 Z. Nowakowski, „Pan Juliusz”, „Lwów i Wilno” 1947 nr 25, cyt. za: Z. Osiński, Pamięć Reduty. Osterwa, Limanowski, Grotowski, Gdańsk 2003, s. 152-154.

31 Zob. M. Orlicz, op. cit., s. 160-161. 
W 1925, kiedy zespół oczekiwał na koniec remontu nowej siedziby w Wilnie, odbyły się aż cztery wyprawy, z których ostatnia zakończyła się późną porą zimową -6 grudnia. ${ }^{32}$ Sam Osterwa wyruszył 1 września z Przepióreczka, drugą grupę wysłał na północ, do miejscowości, w których stacjonowało Wojsko Polskie, z Wieczorem poezji polskiej (w programie były też fragmenty Popiołów). ${ }^{33}$ Podczas objazdu 4 listopada 1925 odbyła się w Suwałkach premiera Wesela. Ostatnia wyprawa z tego roku, pomiędzy 4 listopada a 6 grudnia, wiozła w repertuarze aż sześć przedstawień (Wesele, W matym domku, Fircyka w zalotach, Przepióreczke, Hołd Mickiewiczowi - złożony z fragmentów i wybranych utworów wieszcza, Nowego Don Kiszota czyli Sto szaleństw Fredry oraz koncert polskich piosenek) i zakończyła się pokazami na Łotwie.

W 1926 odbyła się pomiędzy czerwcem a sierpniem pierwsza wyprawa z Księciem Niezłomnym, pokazywanym w plenerze. Jak oblicza Bożena Frankowska, Reduta odwiedziła wówczas 10 miast, dając 19 przedstawień - przed gmachami kościołów (Lwów), na Wawelu, na dziedzińcach (Wilno, Poznań), w warszawskich Łazienkach czy na miejskim rynku (Wejherowo). ${ }^{34}$ Jednak „największą w historii polskiej sceny wyprawą artystyczną po kraju" 35 był złożony z trzech grup objazd w 1927. Pierwsza grupa wyruszyła jeszcze w maju ze Ślubami panieńskimi, druga po niej - z Cydem, a 4 czerwca ruszyła największa, dowodzona przez Osterwę, grupa z Księciem Niezłomnym ${ }^{36}$. Odwiedziła ona od 4 czerwca do 11 września 60 miast, dając 62 spektakle i, jak pisze Szczublewski, dokonując „choćby tylko w historii polskiej organizacji widowisk czegoś zupełnie przedtem nieosiągalnego". ${ }^{37}$ Jak stwierdza Frankowska: „W 1926 i 1927 Reduta zapoznała z dramatem Słowackiego połowę ludności Polski". ${ }^{38}$ Każda z grup była w objeździe około trzech miesięcy, odwiedzając dosłownie cały kraj i dając pokazy w sumie w 150 miastach. Jak podaje Szczublewski, po pierwszych 900 dniach istnienia Reduta wędrowna dała łącznie 1502 przedstawienia w 173 miejscowościach, ${ }^{39}$ po czterech sezonach działalności (1925-1929) było to już ponad 1800 przedstawień. ${ }^{40}$

Pomiędzy 1929 a 1932 rokiem Reduta w objazdach po kresach wschodnich i zachodnich, Małopolsce i Pomorzu wizytowała ponad sto miast, dając - jak ustala Zbigniew Osiński - około tysiąca spektakli (wśród prezentowanych autorów byli m.in. Aleksander Fredro, Gabriela Zapolska, Jerzy Szaniawski, Stefan

32 Zob. B. Nycz, Teatr czy uniwersytet?, [w:] O Zespole Reduty 1919-1939. Wspomnienia, Warszawa 1970, s. 191-230.

33 Zob. Listy Juliusza Osterwy, op. cit., s. 66.

34 B. Frankowska, Teatr na-powietrzny Juliusza Osterwy, „Pamiętnik Teatralny” 1970 z. 4, s. 428.

35 J. Szczublewski, op. cit., s. 309.

36 Zob. Z. Osiński,op. cit., s. 145, 577-578; B. Frankowska, op. cit., s. 425- 445.

37 J. Szczublewski, op. cit., s. 285.

38 B. Frankowska, op. cit., s. 426.

39 J. Szczublewski, op. cit., s. 322.

40 B. Śmigielski, Reduta w Wilnie 1925-1929, Warszawa 1989, s. 115. 


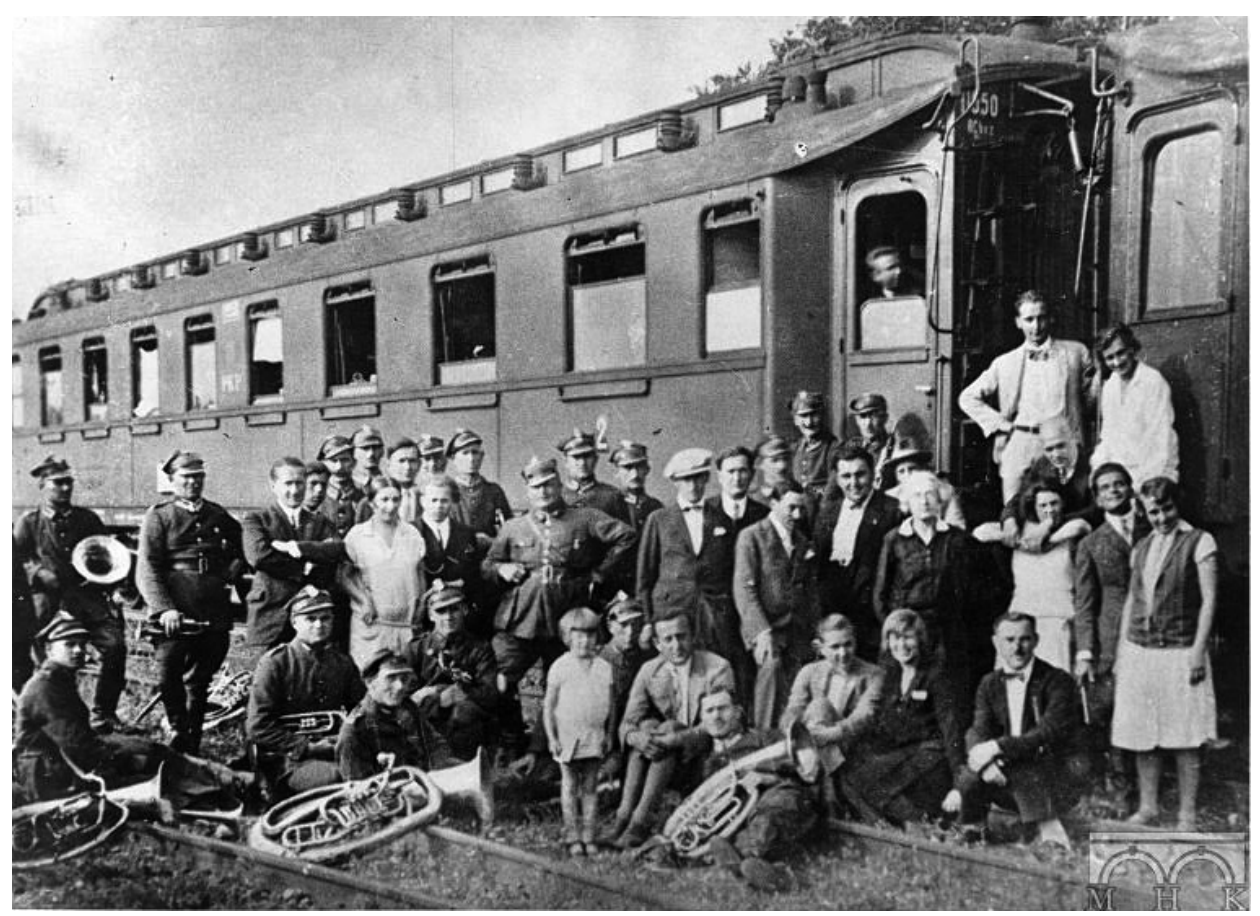

Teatr Reduta w objeździe, Rawicz 1927

Żeromski, Józef Kraszewski, Michał Bałucki). ${ }^{41}$ Dane z lat 1933-1939 są trudne do odtworzenia $\mathrm{z}$ powodu spalenia archiwum i biblioteki Reduty w czasie Powstania Warszawskiego. Osiński rekonstruuje częściowo repertuar i terminy objazdów na podstawie notatek prasowych. ${ }^{42}$ Stąd wiadomo na przykład, że latem 1933 grano w plenerze Wieczór Trzech Króli Shakespeare'a; z Zaczarowanym kołem Rydla objechano w 1933 roku 46 miast; w objazdach pokazano Żeglarza, Ptaka, Adwokata i róże, Lekkoducha, Ewę oraz Murzyna Szaniawskiego, pisarza tak ważnego dla pierwszego warszawskiego okresu Reduty. Dzięki zachowanej mapie wiadomo, że pokazy Mazepy w reżyserii Wiercińskiego odbyły się jesienią 1933 w 70 miastach. ${ }^{43}$ Wielkim sukcesem okazała się Teoria Einsteina Antoniego Cwojdzińskiego, którą pomiędzy czerwcem a sierpniem 1935 wystawiono 101 razy. W latach trzydziestych prezentowani w objazdach byli także autorzy obcy, oprócz Shakespeare’a również Luigi Pirandello, Friedrich Schiller, Charles Dickens, Henryk Ibsen, Nikołaj Gogol, Gilbert Chesterton, William Maugham, George Bernard Shaw, Jean Anouilh, a także autorzy fars, jak: Caillavet i Flers, Eugène Scribe czy Ernest Legouvè.

\footnotetext{
41 Zob. Z. Osiński, op. cit., s. 547-549.

42 Zob. ibidem, s. 550-559.

43 Zob. ibidem, s. 551.
} 
Regularnie powracał Osterwa do Przepióreczki, która, począwszy od roku 1925, pojawiała się w repertuarze Reduty objazdowej do 1938 (ponadto Reduta pokazywała w objazdach Turonia, Sułkowskiego, Ponad śnieg bielszym się sta$n e ̨ . .$. i fragmenty Róży Żeromskiego). ${ }^{44}$

Tuż przed wybuchem wojny Reduta podróżowała od maja do końca lipca 1939 z Powrotem Przełęckiego Jerzego Zawieyskiego, dając pokazy w ponad 40 miastach. To tylko wybrane dane i liczby, gdyż nie chodzi tu o statystyki, a o uświadomienie skali i zasięgu zjawiska, które po dziś dzień budzić może podziw i zdumienie.

Zachowane dokumenty: pamiętniki i korespondencja redutowców (przede wszystkim listy Bronisława Nycza ${ }^{45}$ i Edmunda Wiercińskiego ${ }^{46}$ ) przynoszą interesujące informacje o codziennym życiu w trasie, o miejscach i warunkach, w jakich zespół występował, odbiorze przedstawień czy problemach w czasie podróży. Zachował się Notatnik z objazdu Reduty w 1924 autorstwa młodej adeptki Stanisławy Winiarskiej z marszrutą objazdu i krótkimi uwagami na jej temat ${ }^{47}$, Pamiętnik z I objazdu Reduty Edmunda Wiercińskiego, dotyczący artystycznej strony widowisk $\mathrm{w}$ plenerze ${ }^{48}$ oraz dwa dzienniki Osterwy z przedwojennych objazdów ze spektaklami Uciekła mi przepióreczka... (1 maja - 6 lipca 1938) oraz Powrót Przełęckiego (29 maja - 11 czerwca i 22 czerwca - 27 lipca 1939) ${ }^{49}$. Dzięki tym dokumentom możemy z pierwszej ręki dowiedzieć się, jak olbrzymim przedsięwzięciem była organizacja i skoordynowanie tak dalekich, długotrwałych i wieloosobowych wypraw.

W objazdach były zazwyczaj jednocześnie dwie lub trzy kilkudziesięcioosobowe grupy - każda dowodzona przez kierownika wyprawy (mógł to być Osterwa, Limanowski lub inni doświadczeni redutowcy, np. Edmund Wierciński, Iwo Gall, Jerzy Kossowski, Zygmunt Chmielewski czy Feliks Zbyszewski). Grupy podróżowały wagonami udostępnionymi przez Polskie Koleje Państwowe, oznaczonymi godłem Reduty. Najczęściej były to dwa wagony pulmanowskie (sypialne), jeden wagon towarowy (ze scenografią, dekoracjami i sprzętem technicznym) oraz odkryta platforma (lora), wioząca półciężarowe auto Reduty marki Ford, służące do transportu i przewozu dekoracji na miejscu. W 1927 podczas objazdu z Księciem Niezłomnym do tego zestawu dołączył wagon z kuchnią, który służył za jadalnię i miejsce zebrań. Wagony te były skoordy-

44 Zob. M. Białota, op. cit.

45 B. Nycz, op. cit., s. 191-230.

46 M. i E. Wiercińscy, Korespondencja 1925-1944, t. 1, red. i oprac. M. Piekut, Warszawa 2013.

47 J. Szczublewski, Pierwsza Reduta Osterwy, op. cit., s. 290-294.

48 E. Wierciński, Pamiętnik z I objazdu Reduty, [w:] idem, Notatki i teksty z lat 1921-55, wybór i red. A. Chojnacka, Wrocław 1991, s. 32-54.

49 Dokumenty te pozostają w rękopisach. Fragmenty dziennika z 1939 przedrukował Zbigniew Osiński jako Ostatnia wyprawe przeciw prowincji, [w:] J. Osterwa, Reduta i teatr. Artykuty, wywiady, wspomnienia 1914-1947, oprac. Z. Osiński, Wrocław 1991, s. 283-291. 
nowane z rozkładem jazdy kolei i dołączane do kursujących składów. ${ }^{50}$ Składy Reduty mogły kursować jednocześnie w różnych rejonach Polski lub sukcesywnie, jeden po drugim, na wspólnym obszarze. Grupy mogły się spotykać lub odłączać na trasie. Pojedyncza grupa miała często w repertuarze parę tytułów i mogła dawać kilka przedstawień jednego dnia w danym miejscu (po południu i wieczorem).

W kolejno odwiedzanych miejscowościach czekał na Redutę specjalny „komitet redutowy" złożony z lokalnych urzędników, radców miasta, ludzi kultury, którzy odpowiedzialni byli za zaproszenie zespołu i zapewnienie mu odpowiednich warunków. To z tymi ludźmi, którzy zyskiwali miano Przyjaciół Reduty, kierownictwo objazdu ustalało szczegóły organizacyjne. By wszystko w czasie objazdu funkcjonowało sprawnie, powoływano redutowe referaty (sekcje), które odpowiadały za poszczególne aspekty pracy i współżycia. Istniały więc referaty: gospodarczy, kolejowy, zaopatrzeniowy, techniczny, propagandy, higieny czy pocztowy. ${ }^{51}$

Dział propagandy odpowiadał za reklamę i informację. Do jego zadań należało przygotowanie afiszy, ulotek i cała akcja promocyjna. Osterwa wiele miejsca poświęcił w dziennikach uwagom nad usprawnianiem tego działu i poszukiwaniom sposobów odpowiedniego nagłośnienia przyjazdów Reduty. Zależało mu, by informacja o spektaklach była szeroko rozpowszechniana, a nie zawsze mógł w tej sprawie liczyć na władze miasta. Rozważał więc sposoby informowania telefonicznego, przez radio czy dzięki poczcie, która mogłaby również prowadzić przedsprzedaż biletów. $Z$ odpowiednim nagłośnieniem wiązała się oczywiście frekwencja na spektaklach. Niekiedy redutowcy grali dla kilku zaledwie osób, z drugiej strony, na plenerowe pokazy Reduty przychodziła niejednokrotnie wielotysięczna publiczność. Iwo Gall wspomina, że Księcia Niezłomnego w Częstochowie oglądało 11000 osób, w Poznaniu - 7000, w Stanisławowie 5000.52 Frankowska dodaje jeszcze Krzemieniec z 15000 widzów, Pińsk - 8000 i Nieśwież - 4000. ${ }^{53}$ Były to wielkie, masowe, perfekcyjnie zorganizowane i przemyślane widowiska, które przyciągały tysiące ludzi.

Całomiesięczne wyprawy były wyzwaniem organizacyjnym i artystycznym uczyły redutowców reagować na niecodzienne sytuacje, improwizować. Granie w nowych i codziennie odmiennych warunkach, nie zawsze komfortowych, wymogło nowe praktyki i pomysły inscenizacyjne. W przypadku realizacji Księcia Niezłomnego w plenerze trzeba było przede wszystkim wybrać odpowiedni teren

$50 \quad$ Zob.: M. Orlicz, op. cit., s. 159-175; J. Ciechowicz, Teatr w podróży. Wędrowanie jako poznanie, „Konteksty. Polska Sztuka Ludowa” 2008 nr 1, s. 69-72.

51 Więcej na temat organizacyjnej strony objazdów w: W. Świątkowska, Najwyższe z rzemiost apostoła i najniższa modlitwa anioła - Redutowy etos pracy, [w:] Rzemiosło teatru. Etos - profesje materia, red. A. Dąbek, W. Świątkowska, Kraków 2015, s. 35-55.

52 I. Gall, Mój teatr, Kraków 1963, s. 239.

53 B. Frankowska, op. cit., s. 436. 
gry. W 1926 grano głównie przed fasadami kościołów i na dziedzińcach, przypominających hiszpańskie „,corrales”. W 1927 wybierano raczej otwartą przestrzeń z zabytkowym tłem, stadiony, podnóża wzgórz. Rozbudowano widowiskowość inscenizacji - w przedstawieniu brało udział 40 aktorów, 300 statystów i 300 koni oraz orkiestra wojskowa ${ }^{54}$. Duża przestrzeń pod gołym niebem umożliwiała efektowne sceny batalistyczne, konne pochody, pozwalała też na wykorzystywanie pochodni:

Samo przestawienie było już improwizacją artystyczną. Podczas jego trwania trzeba było spoić poszczególne części, na poczekaniu tworzyć sytuacje, pilnować statystów, utrzymać się na koniu, recytować poezję Słowackiego. Bez suflera i inspicjenta. ${ }^{55}$

Wszyscy redutowcy byli zaangażowani w przygotowanie widowiska, każdy z nich miał wyznaczony odcinek pracy i ,spełniał tylko swoje z góry określone zadanie, które ściśle łączyło się z wytyczonym planem budowania widowiska". ${ }^{56}$ Jedni trenowali statystów, rekrutujących się spośród żołnierzy, harcerzy czy policji, którzy mieli odgrywać grupy niewolników, Maurów i Portugalczyków. Inni opracowywali szczegółowo pojedyncze sytuacje, planowali wjazdy i ruchy wojsk, ćwiczyli jazdę konną czy przygotowywali przestrzeń gry. Eugeniusz Dziewulski niemal codziennie odbywał kilkugodzinne próby z lokalnymi orkiestrami, które musiały szybko opanować ilustrację muzyczną. Dzięki doskonałej organizacji praca przebiegała sprawnie, ,bez żadnego dyktanda, bez nawoływań, bez żadnego zamieszania". ${ }^{57}$

\section{Michał Orlicz zauważał:}

Podróże te stały się trainingiem [!] fizycznym dla młodego zespołu, który dzięki ułatwieniom kolejowym ze strony Rządu objechał tereny Rzeczypospolitej pobudzając życie kulturalne inteligencji, pozbawionej na prowincji dobrego teatru. Przytem pośpiech, z jakim nieraz trzeba było na danym postoju przygotować widowisko wobec ściśle w innych miastach wyznaczonego terminu podróży, animował aktorów Reduty tak bardzo i tak korzystnie wpływał na prężność energii i artystyczną pobudliwość zespołu, że rodziły się niespodziewanie, rzekłbyś na poczekaniu, cacka kunsztu teatralnego. ${ }^{58}$

W roku 1925 Osterwa w liście do Żeromskiego pisał z dumą:

Nie wypada mi chwalić moich ukochanych redutowców, ale muszę powiedzieć, że prowincja dawno chyba nie widziała takiego zespołu. ${ }^{59}$

Wyprawy miały ogromną funkcję propagatorską - na przedstawienia przychodziły tłumy żądne dobrego teatru. Wielotysięczną publiczność Księcia Niezłomnego

\footnotetext{
54 Zob. I. Gall, op. cit., s. 239.

55 B. Frankowska, op. cit., s. 443-444.

56 M. Orlicz, op. cit., s. 164.

57 Ibidem

58 Ibidem, s. 159.

59 Listy Juliusza Osterwy, op. cit., s. 66.
} 
przyciągała strona artystyczna, ale także rozgłos, nadany wydarzeniu (Reduta organizowała spektakle we współpracy z komitetem sprowadzenia zwłok Juliusza Słowackiego do kraju) oraz systematyczność objazdów Reduty, na którą czekano niecierpliwie i z radością. Jak wspominał Nowakowski

W Łunińcu, w Sarnach, w Ostrogu, w Krzemieńcu wszystko czekało na przyjazd Reduty, gdyż było to wielkie święto: teatr, teatr prawdziwy przyjechał! ${ }^{60}$

Celem Reduty było regularne odwiedzanie jak najmniejszych ośrodków, docieranie „do ludzi, którzy jeszcze nigdy nie widzieli teatru ani nie słyszeli piękna słowa ojczystego". ${ }^{61}$ Iwo Gall we wspomnieniu o Osterwie notował:

$\mathrm{Z}$ całą satysfakcją występował [Osterwa] w tych biednych, małych miasteczkach; uważał to sobie za wielki honor i podniecał swoich aktorów do rozmiłowania się właśnie w takiej pracy, służeniu wszystkim obywatelom, całemu społeczeństwu, zerwania $\mathrm{z}$ teatrem elitarnym. Osterwa nigdy nie uznawał sztuki dla sztuki, chociaż długie lata tkwił w teatrach merkantylnych. ${ }^{62}$

Widoczna jest $\mathrm{w}$ tych słowach służebna rola teatru wobec społeczeństwa, jego funkcja edukacyjna, pragnienie rozpowszechnienia go oraz przywrócenia mu ważnej roli społecznej i popularności. Miał to być teatr masowy, popularny, jednak o najwyższym poziomie artystycznym, a nie tandetny i bezwartościowy, jak występy tych ,niepoczytalnych band artystyczno-opryszkowych, które tu od lat deprawowały publiczność" ${ }^{3}$ - jak wyrażał się Osterwa o tradycyjnych trupach objazdowych. W wywiadzie, przeprowadzonym przez Jalu Kurka w Krakowie w roku 1929, Osterwa następująco tłumaczył swe motywacje:

Dlaczego jeżdżę po Polsce? Nie tu jest przyszłość teatru - w tych ciasnych, dusznych klatkach. Ja chcę grać na powietrzu. Widowisko - oto jest forma współczesnej sztuki teatralnej. Jeździmy po Polsce. Chcemy się dobrać do tego społeczeństwa, które żyje z dala od zgiełku wielkich miast. Niech i oni przez chwilę poczują dreszcz wielkiego słowa, niech i ich przerazi i olśni wizja prawdziwej, żywej sztuki. Wie pan - oni tam lepiej to nawet czują. U nich to, czego my szukamy - ten skurcz serdeczny, ten płacz duszy jest tuż za skórą. Do niego chcemy się dobrać. ${ }^{64}$

Patrząc na dorobek Reduty wędrownej, można z przekonaniem stwierdzić, że Osterwa zrealizował swoje marzenie o idealnym zespole objazdowym. Dzięki własnej determinacji oraz zaangażowaniu i poświęceniu redutowców, a także wsparciu sił rządowych i lokalnych władz zorganizował na niespotykaną dotąd w Polsce skalę wielką akcję teatralną. Reduta wędrowna, pisał Gall,

$60 \quad$ Cyt. za: Z. Osiński, op. cit., s. 153.

61 I. Gall, op. cit., s. 232.

62 Ibidem, s. 232-234.

63 Listy Juliusza Osterwy, op. cit., s. 157.

64 Pól godziny z Juliuszem Osterwą, „Głos Narodu” 23 X 1929 [w:] J. Osterwa, Reduta i teatr, op. cit., s. 130-131. 
to była jego duma i w tej właśnie formie działania teatru widział przyszłość Reduty jako jedynego istotnie zespołowego teatru polskiego, krzewiącego wśród mas rodzimą twórczość dramatyczną od klasycznej do współczesnej”. ${ }^{65}$

\section{TEATR SPOŁECZNY}

Pomysły reformy organizacji widowisk na prowincji i stworzenia nowoczesnego teatru dla masowego odbiorcy powstały w czasie drugiej wojny światowej i przybrały miano Teatru Społecznego.

Warunki, w których Reduta musiała grać podczas objazdów, były często fatalne. Osterwa niejednokrotnie narzekał na małe, brudne, nieprzystosowane do widowisk sale (grali w budynkach szkolnych, salach gimnastycznych, remizach strażackich, zajezdniach, szopach, a nawet w parowozowni), ciasne garderoby lub ich brak, złą organizację ze strony miejscowych władz czy brak promocji. Ponadto Osterwa krytykował koszty pokazów i nie zawsze uczciwe podejście ze strony lokalnych organizatorów. W liście do Tadeusz Białkowskiego pisał:

Kropią za sale tak, jak hotele maharadży za granicą. Jedyna okazja. Mają dochodu z kin po 7 zł - to Reducie np. 170. Sale stoją puste - to chcą, żeby jednorazowy pobyt Reduty opłacił im komorne całoroczne, co najmniej miesięczne, no to $1 / 2$ miesięczne. ${ }^{66}$

$\mathrm{Z}$ niezadowolenia z warunków podczas objazdów i pragnienia zreformowania organizacji życia teatralnego wyrosła koncepcja Teatru Społecznego. Osterwa pragnął stworzyć ogólnopolską, skoordynowaną sieć placówek i działań teatralnych, która powstałaby jako inicjatywa oddolna przy współudziale miejscowych władz i zaangażowaniu lokalnej społeczności. Prowadzić je powinny ośrodki teatralne zlokalizowane początkowo w większych miastach, które zasięgiem swych działań obejmowałyby poszczególne regiony. Miały one organizować działalność objazdową i tak jak Reduta wędrowna docierać z przedstawieniami do najmniejszych miejscowości.

Wstępne projekty snuł Osterwa jeszcze przed wojną - wiosną 1939. Pierwsza placówka winna powstać w Warszawie pod patronatem Ministerstwa Opieki Społecznej. Prace przygotowawcze miały ruszyć w lipcu i sierpniu, a przedstawienia rozpocząc się we wrześniu 1939, co udaremnił wybuch wojny. ${ }^{67} \mathrm{~W}$ prowadzonych podczas okupacji raptularzach Osterwa udoskonalał tę ideę, licząc, że będzie można ją wprowadzić w życie po zaprzestaniu działań wojennych. Projekt ten nigdy nie doszedł do skutku - Osterwa nie przewidział, że wojna będzie trwała sześć lat i doszczętnie zrujnuje kraj. Nie mógł również wiedzieć, jaki ustrój i zasady zostaną narzucone przez wyzwolicieli. W końcu nie mógł przeczuwać, że po zakończeniu wojny pozostaną mu już tylko dwa lata życia.

\footnotetext{
65 I. Gall, op. cit., s. 238-239.

66 Listy Juliusza Osterwy, op. cit., s. 157.

67 Zob. J. Szczublewski, Żywot Osterwy, op. cit., s. 444.
} 
W przeciwieństwie do Reduty objazdowej, idea Teatru Społecznego nigdy nie weszła w życie. Pozostały po niej wyłącznie plany i projekty na papierze, pomysły, które nie zostały zrealizowane. Można je prześledzić i zrekonstruować na podstawie zachowanych raptularzy i dzienników wojennych Osterwy. Najważniejszy dla określenia charakteru tej idei teatru jest przymiotnik „społeczny”. W raptularzu z 1945 Osterwa definiował:

„Społeczny” znaczy tyle, co „powszechny”. S p o ł e c z n y - więc przeznaczony dla społeczeństwa - dla wszystkich warstw społeczeństwa - czyli dostępny dla chłopów, robotników i umysłowców, dostępny dla młodzieży szkół powszechnych, średnich i wyższych, i zawodowych - dla ich rodziców i wychowawców. ${ }^{68}$

Teatr Społeczny miał być teatrem szeroko dostępnym, popularyzatorskim; miał służyć wspólnocie, wyrastać z jej potrzeb i pełnić funkcje edukacyjne i socjalne. Teatr Społeczny oznaczał tak naprawdę ,teatr społeczeństwa - teatr wspólnoty, wspólnoty narodowej”. ${ }^{69}$ Był to teatr nastawiony na widza masowego, który miał gromadzić

przedstawicieli pełnego polsk[iego] społeczeństwa: i młodzież, i starszych, burżuazję i proletariat - stolicę i wieś, i osady robotnicze. ${ }^{70}$

Reorganizacja życia teatralnego polegała na stworzeniu w każdym ośrodku w Polsce (począwszy od największych - Warszawy, Łodzi, Krakowa, Gdańska, Poznania, Katowic, Torunia, Lublina, Częstochowy, by stopniowo objąć zasięgiem i mniejsze miejscowości) podobnie zorganizowanych placówek, $\mathrm{z}$ analogicznie działającą administracją, zespołem artystycznym i repertuarem. W raptularzu z grudnia 1940 Osterwa nazwał te placówki „Domami Społecznymi”. Powinny one mieć scenę „o jednakich rozmiarach obowiązujących w całym kraju” "ᄁ1, ale również salę kinową, w której można by było prowadzić też wykłady (odczyty), salę wystawową (wystawy malarstwa i rzeźby), zaplecze muzyczne z instrumentami i sprzętem radiowym (sala koncertowa, taneczna) oraz magazyny na dekoracje i kostiumy. Miały to być nowocześnie zorganizowane, wielofunkcyjne „domy kultury”, które stałyby się ważnymi centrami wszelkich działań kulturalnych w danym mieście.

Osterwa chciał, by za prowadzenie tych placówek odpowiedzialne były towarzystwa, których członkowie rekrutowaliby się z działaczy społecznych i ludzi kultury danego miasta. W notatce raptularzowej z 1940 wyraźnie planował, by była to inicjatywa oddolna:

68 J. Osterwa, Raptularz, 15 IV-VII 1945, [w:] I. Guszpit, Juliusza Osterwy parafraza „Antygony”, ,Acta Universitatis Wratislaviensis” no 418, Prace Literackie XIX, Wrocław 1977, s. 183.

69 I. Guszpit, D. Kosiński, Ku Teatrowi Spotecznemu, [w:] J. Osterwa, ,Antygona”, „Hamlet”, „,Tobiasz” dla Teatru Spolecznego, Wrocław 2007, s. 14.

70 J. Osterwa, Raptularz, VI-VIII 1940, [w:] idem, ,Antygona”, „Hamlet”, „Tobiasz” dla Teatru Społecznego, op. cit., s. 121.

71 Idem, Raptularz, XII 1940, [w:] idem, Przez teatr-poza teatr, wybór i oprac. I. Guszpit, D. Kosiński, Kraków 2004, s. 227. 
Niechże więc jednostek kilka zbierze się i utworzy t o w a r z y s t w o, które się zajmie: jasnym postawieniem sprawy:

określi swój zamiar - cel,

drogi i środki zmierzające do tego celu

i niech się zdecyduje na wspólne przepisy - oparte na prawie wedle ustawy.

Celem towarzystwa jest:

A) organizacja, uregulowanie sprawy T[eatru] w społ[eczeństwie] p[olskim] przez:

a) dokładne zbadanie jego celowości istnienia w społ[eczeństwie],

b) utrzymanie jego bytu, zapewnienie rozkwitu ku pożytkowi społ[eczeństwa] p[olskiego]. ${ }^{72}$

Towarzystwa miały odpowiadać za budynek teatralny, zorganizowanie zespołu artystycznego i pomocniczego, repertuar, miały mianować kierowników artystycznych i zarządców teatru, zakładać uczelnie teatralne, organizować widownię, kontaktować się z władzami i nawiązać stosunki z innymi teatrami, by „uzgodnić pracę wspólną". ${ }^{73} \mathrm{Z}$ czasem Osterwa planował, by pieczę i kontrolę nad lokalnymi jednostkami sprawowało Ministerstwo Kultury i Sztuki, co miało się przyczynić do skoordynowania i ujednolicenia działań w całym kraju.

Niezmiernie ważny był dla Osterwy jednolity repertuar tych teatrów. Teatr Społeczny miał z założenia pełnić funkcje edukacyjne i propagować polską twórczość dramatyczną. W raptularzu z 1945 Osterwa zapisał:

Teatr Społeczny wystawia utwory, które są owocami rodzimej twórczości, zwłaszcza utwory o treści historycznej [...] oraz takie z obcego piśmiennictwa, które mają lub mogą mieć wpływ na rozwój wszechtwórczości rodzimej, lub które ściśle są związane z zagadnieniami umysłowego życia w Polsce. ${ }^{74}$

\section{Z dzieł obcych}

będą brane pod uwagę tylko te - które miały dodatni wpływ bezpośredni na twórczość polską i zostały spolszczone: arcydzieła klasyczne, Szekspir, Calderon, Molier, Corneille (tłumaczenia przekłady ze współcz[esnego] piśmiennictwa - będą niedopuszczalne aż do odwołania) ${ }^{75}$

W repertuarze znalazłaby się zatem przede wszystkim dramaturgia polska i przystosowana do oczekiwań polskich odbiorców klasyka europejska. Na czym polega owo dostosowanie do odbiorców, thumaczył w raptularzu z 1940. Przede wszystkim repertuar miał być zróżnicowany i „dobrany do stopnia dojrzałości umysłowej" 76 : odpowiedni dla dzieci i młodzieży, inny dla robotników, jeszcze inny dla inteligencji. Oczywiście - zaznaczał Osterwa - są też utwory odpowiednie dla wszystkich warstw. Po drugie, utwory obcego pochodzenia powinny ulec zmianom, które ułatwiłyby ich odbiór, uprzystępniły treść i wpisały je w obręb

\footnotetext{
72 Ibidem, s. 228.

73 Ibidem.

74 J. Osterwa, Raptularz, 15 IV-VII 1945, [w:] I. Guszpit, op. cit., s. 183.

75 J. Osterwa, Przez teatr - poza teatr, op. cit., s. 236-237.

76 Ibidem, s. 261.
} 
kultury narodowej. Specjalnie powołany urząd miał zajmować się „,zbieraniem utworów scenicznych i ich odpowiednim opracowaniem". ${ }^{77}$

Jak takie zabiegi adaptacyjne wyglądałyby w praktyce, pokazują trzy parafrazy Osterwy przeznaczone dla Teatru Społecznego, powstałe w czasie wojny: Antygona według Sofoklesa (1939), Hamlet Szekspirowski (1940) oraz misterium o Tobiaszu (1944). ${ }^{78}$ Antygona została przez Osterwę uwspółcześniona (przeniesiona w realia historyczne kampanii wrześniowej 1939 i początków okupacji), spolszczona (przez dobór cytatów z literatury polskiej) i wpisana w światopogląd chrześcijański (z chrześcijańską koncepcją kataklizmu, ideą oczyszczenia przez samooskarżenie i uznaniem wartości pokory) ${ }^{79}$. Hamleta Osterwa spolonizował (polska lokalizacja i realia, aluzje do literatury polskiej), uprościł (usunięcie niejasnych fragmentów, wytłumaczenie miejsc wieloznacznych), uprzystępnił i uwspółcześnił w warstwie językowej (wprowadzenie języka potocznego, polskich idiomów i przysłów) i zreinterpretował w duchu religii i moralności katolickiej (pod wpływem Księcia Niezłomnego Słowackiego i Studium o Hamlecie Wyspiańskiego) ${ }^{80}$ Jak sam wyjaśniał - tłumaczył Hamleta nie po to, żeby się podobał lub nie podobał, tylko żeby działał, by był lekcją dla ludzi żyjących w okupowanym kraju i pokazał, jak z hamletyzowania dorosnąć do niezłomności. ${ }^{81}$

Dzięki tego rodzaju adaptacjom Osterwa wprowadzał klasyczne dramaty obce w krąg polskiej tradycji literackiej - głównie romantycznej, spod znaku Słowackiego, Mickiewicza i Wyspiańskiego. Repertuar Teatru Społecznego odwoływał się do wyobraźni narodowej i miał spełniać obowiązek budowania polskiej tradycji teatralnej.

Repertuar Teatru Społecznego miał wpisywać się w „kalendarz przyrody, liturgii i historii" ${ }^{2}$ i dzięki temu konstytuować wspólnotę i organizować życie zbiorowe. „Teatr Społeczny tworzyć miał nie spektakle, ale wokółteatralne święta, kulturowe performanse będące wyrazem wartości scalających wspólnotę" ${ }^{83}$. Dla Osterwy wartości te wyrastały z trzech porządków: religii katolickiej, historii Polski i tradycji widowisk obrzędowych. Organizację roku repertuarowego zanotował Osterwa w raptularzu z grudnia 1940. Kalendarz pokazów zorganizowany został według religijnych i patriotycznych świąt narodowych. ${ }^{84}$ I tak na 6 stycznia, czyli święto Trzech Króli, zaplanował pokazanie Pastorałki, w rocznicę wybuchu powstania styczniowego teatr miałby wystawić Dyktatora

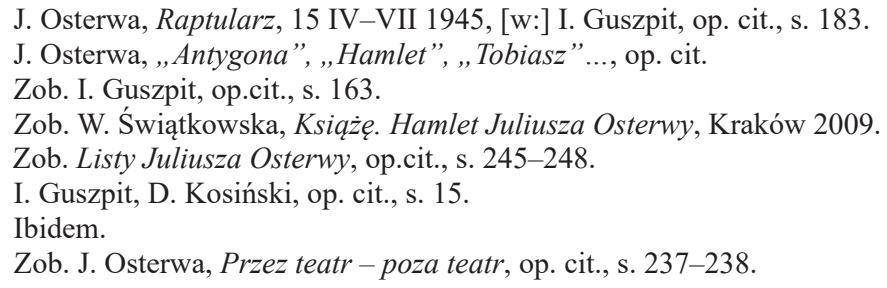


Jerzego Żuławskiego i Wierna rzekę według Żeromskiego, w rocznicę powstania listopadowego - Warszawianke lub Noc listopadowa Wyspiańskiego. Na karnawałowe zapusty Osterwa przewidywał komedie, np. Dom otwarty Bałuckiego lub utwory Józefa Blizińskiego. W środę Popielcową chciał prezentować dramaty o Judaszu - Karola Huberta Rostworowskiego (Judasz z Kariothu) i Kazimierza Przerwy-Tetmajera (Judasz). Rocznicę bitwy pod Racławicami planował uczcić spektaklem Kościuszki pod Racławicami Anczyca, a uchwalenie Konstytucji 3 Maja Powrotem posła Niemcewicza. Jak zauważają wydawcy parafraz

Tak zorganizowany Teatr Społeczny stałby się realizacją marzenia Mieczysława Limanowskiego, zapisanego w pochodzącym jeszcze z 1916, niezwykle inspirującym tekście Rok polski i dusza zbiorowa. Stałby się teatrem ekologicznym i wspólnotowym, przestając być rozrywkowym dodatkiem do życia poważnego - stałby się istotną częścią żywej kultury wspólnoty, a być może i jednym z najważniejszych narzędzi, kulturę tę na nowo ustanawiających. ${ }^{85}$

Jak widać, planowany teatr miał prezentować repertuar ,społeczno-użytkowy”, czyli taki, który przyniesie największe korzyści wspólnocie. Powinien ją zapoznawać z polskim dorobkiem dramatycznym i odpowiednio dostosowaną dramaturgią europejską, edukować, rozwijać duchowo, jak również współgrać z kalendarzem świąt i żywymi tradycjami obrzędowo-widowiskowymi. A także szerzyć „wytworność, ogładę, smak” i jednoczyć ludzi wokół „,̇ywego polskiego Słowa" ${ }^{86}$ Teatr Społeczny miał pielęgnować i wzbogacać polską kulturę oraz rozpowszechniać narodowe tradycje.

Celem Osterwy było - jak notował w diariuszu - „wcieranie, wmasowywanie" ${ }^{87} \mathrm{w}$ publiczność polskiej kultury i przekazywanie jej w uprzystępnionej formie, czemu miały służyć prelekcje przed spektaklami czy specjalnie przygotowane ulotki. W raptularzu zapisał:

Przedstawienie w T[eatrze] Społ[ecznym] bywa poprzedzone przedsłowiem żywym, które objaśnia znaczenie utworu [...] i celowość wystawienia. ${ }^{88}$

Spektakle, przygotowane przez zespół profesjonalistów, miały stać na najwyższym artystycznym poziomie, zarówno pod względem wystawy, jak i wykonania. W skład zespołu artystycznego powinno wchodzić „24 mężczyzn, 12 kobiet [...] w zapasie 6 m[ężczyzn], 3 kobiety, Razem: $30 \mathrm{~m}$ [ężczyzn] + 15 ko$b[i e t]$ "89. Zespół ten winien prowadzić regularne objazdy po okolicy i „promieniować nie tylko na mieszkańców, lecz na wszystkich w kraju"90. A wtedy skończą

\footnotetext{
85 I. Guszpit, D. Kosiński, op. cit., s. 16.

86 J. Osterwa, op. cit., s. 230.

87 J. Szczublewski, op. cit., s. 450.

88 J. Osterwa, Raptularz, 15 IV-VII 1945, [w:] I. Guszpit, op. cit., s. 183.

89 Ibidem, s. 184.

90 J. Osterwa, Przez teatr - poza teatr, op. cit., s. 233.
} 
się - przewidywał Osterwa - przedwojenne pojęcia o „prowincji” i ,zapadłych dziurach"91.

Teatr Społeczny miał więc być nie tyle pojedynczą instytucją, co cała siecią podobnych placówek kulturalnych na terenie kraju. Projekt ten był szeroko i starannie zakreśloną przez Osterwę reformą znanego mu sprzed wojny życia teatralnego, jego całkowitą reorganizacją i modernizacją, którą miał nadzieję zrealizować w rzeczywistości powojennej. Jego celem było umożliwienie dostępu do kultury teatralnej wszystkim warstwom społeczeństwa we wszystkich regionach Polski. Jak piszą wydawcy parafraz,

teatr miał spełniać rolę wydarzenia społecznego, wokół którego zdezintegrowane środowisko miejskie będzie mogło odbudować i na nowo ustanowić wspólnotę spójnej kultury.92

W 1938 w Notatkach do wspomnień Osterwa zapisał: „teatr ma potężne znaczenie społeczne i wpływ, i moc" ${ }^{93}$. Te słowa dobitnie wskazują, że u podstaw artystycznej i społecznej ideologii Osterwy leżała wiara w teatr. Sztuka, w myśl imperatywów Norwida i Wyspiańskiego, miała według niego szansę zmieniać rzeczywistość. Doświadczenie teatralne mogło kształtować postawy indywidualne i społeczne, co wyraźnie potwierdzają trzy wybrane przeze mnie przykłady z drogi twórczej Osterwy.

Wypada zgodzić się z Marią Osterwą-Czekaj, że jej ojciec w każdym swoim działaniu był przede wszystkim społecznikiem. Niezależnie od poszczególnych etapów tej drogi, zmian profilu Reduty, koncepcji, które narodziły się w czasie wojny, Osterwie zawsze przyświecał cel społeczny, pragnienie stworzenia teatru sytuującego się w relacji ze społeczeństwem i wrażliwego na potrzeby odbiorców. Najważniejszy był dla niego zawsze teatr i to, by ten teatr dotarł do ludzi.

$91 \quad$ Ibidem, s. 267.

92 I. Guszpit, D. Kosiński, op. cit., s. 15.

93 J. Osterwa, Notatki do wspomnień, „Scena Polska” 1938 z. 2-3, [w:] idem, Reduta i teatr, op. cit., s. 233. 